RESENHA

\title{
Entre a América e a Europa: a política externa do Brasil nos anos 1920*
}

PAULO ROBERTO DE ALMEIDA**

O livro resulta de tese de doutorado apresentada na UnB em 2001 e beneficiou-se de pesquisas do autor em arquivos nacionais e estrangeiros (EUA e Reino Unido), com o que ele construiu uma obra tão competente quanto necessária, uma vez que o período coberto permanecia uma espécie de "patinho feio" da nossa historiografia diplomática, prensado entre a "era do Barão", na primeira década do século XX, e os episódios mais "excitantes" da fase da Guerra Fria. No próprio entre-guerras, os anos de depressão e conflitos econômicos e militares que se seguiram à crise de 1929 sempre receberam mais atenção dos historiadores que o período aparentemente "morno" que se situa entre o final da Primeira Guerra e o golpe de outubro de 1930, que inaugura a chamada era Vargas, de modernização e industrialização.

Eugênio Garcia formula, em primeiro lugar, uma série de perguntas, que ele tenta depois responder em sete capítulos temáticos que cobrem as principais áreas de atuação e os principais problemas diplomáticos - e desafios internacionais - do Brasil nos doze anos cobertos pela pesquisa. Como a política externa movia-se num triângulo atlântico formado pelos Estados Unidos, Europa e América do Sul, suas perguntas se dirigem aos problemas que serão depois analisados em cada um dos capítulos: "rumo à Europa", ou seja, nossa participação na conferência da paz de 1919; "diplomacia econômica", vale dizer, defesa do café e penetração de capitais estrangeiros; "equilíbrio estratégico na América do Sul", com o rearmamento militar e as tentativas de equilíbrio de poderes na região; "comércio e finanças", quando se assiste à competição entre os interesses britânicos e americanos nas duas vertentes; "a experiência da Liga das Nações", nossa primeira tentativa, frustrada, de integrar o círculo dos "mais iguais"; "de volta à América", quando se administra o afastamento diplomático da Europa; e "a diplomacia anti-revolução das oligarquias", capítulo

\footnotetext{
* Resenha de GARCIA, Eugênio Vargas. Entre América e Europa: a política externa brasileira na década de 1920. Brasília: Editora da Universidade de Brasília; Funag, 2006, 672 p.; ISBN: 85-230-0854-3

** Diplomata de carreira, professor no mestrado em Direito do Centro Universitário de Brasília - Uniceub. (pralmeida@mac.com).
} 
final no qual aparecem os problemas político-ideológicos que desembocariam na revolução de 1930.

Ele lembra que os chanceleres não eram necessariamente diplomatas profissionais, mas a elite política oligárquica ocupava quase todos os postos do Itamaraty. $\mathrm{O}$ processo decisório já era, então como agora, centrado na figura do presidente, mas alguns estados faziam sua própria "política externa" ao dominarem, por exemplo, a "diplomacia do café" ou emitindo títulos da dívida estadual diretamente nos mercados financeiros internacionais. Uma constatação se impõe, em diversos episódios narrados no livro, e não apenas na saída patética da Liga das Nações em 1926 - objeto de livro anterior do autor -, a de que o Brasil estava só na América, mais ou menos hostilizado pelos vizinhos hispânicos e tratado com a famosa negligência benigna pela grande potência hemisférica. O elemento estrutural decisivo, que permeia a maior parte dos fatos e processos políticos registrados no período, é a transição da velha influência inglesa para a nova hegemonia americana, que se torna evidente no comércio, mas crescentemente também nas finanças e nos investimentos.

Eugênio Garcia faz um uso competente dos ofícios de embaixada e dos despachos da Secretaria de Estado, que se inserem no texto de forma quase natural, o que torna a leitura de seu maçudo opus histórico um empreendimento agradável, quase um racconto storico linear e imediatamente compreensível a despeito dos meandros sofisticados de uma época que supostamente se caracterizaria por ostentar uma "diplomacia ornamental e aristocrática". O cuidado na manipulação dos documentos se revela, por vezes de forma anódina, na transcrição de uma expressão imediatamente é explicada na nota de rodapé: "anotação à margem do telegrama x". Cada capítulo temático cobre não só todo o período analisado, mas por vezes recua à fase anterior à Primeira Guerra, denotando um sólido conhecimento da literatura secundária e uma perfeita apreensão do contexto mais amplo no qual se inseria o problema tratado no capítulo.

O legado dos anos 1920, para nossa diplomacia, é provavelmente o nascimento do conceito de "hemisfério ocidental", que tanta importância teria, para o bem e para o mal, no período da guerra fria. Nossa aproximação com os Estados Unidos se consolidou e, na verdade, nunca chegou a ser desmentida, mesmo a despeito de fases mais ou menos "independentes". A hegemonia ideológica do pan-americanismo só parece ter se esgotado com o próprio fim da guerra fria, ainda que os militares tenham, paradoxalmente, maior grau de responsabilidade no afastamento relativo em relação à potência hegemônica do que os esquerdistas e opositores políticos do "imperialismo americano".

Nem o estilo, nem a substância das questóes diplomáticas dos anos 1920 sobreviveram até a nossa época, com exceção, talvez, da tradicional desconfiança dos vizinhos em relação a um vizinho que não ostenta, obviamente, a mesma arrogância da "nova Roma", mas que tampouco tem o mesmo poder de atração 
do gigante hemisférico. Nossa política externa "dialética” para o hemisfério ora mais próxima dos EUA, em outras ocasióes propensa ao congraçamento no sul - é examinada com competência por Eugênio Garcia, que demonstra, cabalmente, que os mitos do "alinhamento automático" e da "relação especial" sempre foram, então como agora, nada mais do que mitos. A saída da Liga das Naçóes nos afastou durante muito tempo da Europa, mas, como demonstra o autor, essa transição estava longe de ser uma certeza nos anos 1920. 